\title{
Tolerance of Prunus Rootstock to Potassium Carbonate-induced Chlorosis
}

\author{
Yan Shi' and D. H. Byrne ${ }^{2}$ \\ Department of Horticultural Science, Texas A\&M University, College Station, TX 77843-2133
}

\begin{abstract}
Additional index words. Prunus persica, iron chlorosis, calcareous soil, chlorophyll.
Abstract. A standardized screening procedure for tolerance to bicarbonate-induced Fe chlorosis using a commercial fertilizer mix (Plantex) as the nutrient source, high solution $\mathrm{pH}(8.5)$ and $1.5 \mathrm{~mm}$ bicarbonate to simulate a calcareous soil situation was used with a 1 vermiculite :1 perlite (v/v) support media, small pots and topping (pinching back the tops of shoots). The tolerance level of peach [Prunus persica (L.) Batsch] rootstock could be assessed by leaf visual-chlorosis ratings and Spad-502 chlorophyll readings instead of extractable leaf-chlorophyll concentration or plant Fe concentration. Although most of the tolerant genotypes had almond [ $P$. amygdalus (Mill.) D.A. Webb] in their parentage, a few peaches ('Swat', NJ672281007) showed high to moderate levels of tolerance.
\end{abstract}

Iron chlorosis is a problem in calcareous soils throughout the world in commercial stone fruit production areas (Byrne et al., 1990). Peaches grown in these soils develop lime-induced $\mathrm{Fe}$ chlorosis in young leaves due to Fe deficiency (Egilla and Byrne. 1989: Wallace and Lunt, 1960). Although the application of' $\mathrm{Fe}$ chelates can alleviate this problem. this approach is expensive. An alternative approach is the use tolerant rootstock. Peach rootstock demonstrate a range of tolerance to calcareous soil (Byrne, 1988; Egilla and Byrne, 1989). Unfortunately, the literature is full of conflicting reports concerning their relative tolerance (Rem. 1983; Layne, 1987).

Bicarbonate has been implicated as the major causal factor in the development of $\mathrm{Fe}$ chlorosis in both calcarcous soils and solution culture systems (Chancy et al., 1989). Consequently, bicarbonate has been used in solution culture systems to mimic the effects of calcareous soils. In soybeans, the tolerance in bicarbonate-induced chlorosis is well $\mathrm{cm}$-related to tolerance to chlorosis in calcareous soils (Coulombe et al.. 1984; Dragonuk et al., 1989). Preliminary work with peach rootstock has shown that rootstock tolerant and susceptible to lime-induced chlorosis in calcareous soils are easily distinguished in the greenhouse when grown in a perlite-vermiculite pot mix and watered with a high bicarbonate nutrient solution (Byrne et al., 1990).

The objectives of this study were to 1 ) assess the correlation of leaf visual-chlorosis ratings with Spad-502 chlorophyll readings (with chlorophyll meter made by Minolta Camera Co., Ltd., Japan) and extractable leaf-chlorophyll concentration, and 2) determine the relative tolerance level of 48 Prunus accessions to potassium carbonate induced chlorosis.

\section{Materials and Methods}

Seedling establishment. Stratified seeds with roots 1 to $2 \mathrm{~cm}$ long were planted in the greenhouse in pots $\left(310 \mathrm{~cm}^{3}\right)$ with a medium composed of I vermiculite : 1 perlite (v/v). Plantex (Plantco Inc., Canada) nutrient solution prepared with reveiw osmosis purified water $\left(0.57 \mathrm{~g} \cdot \operatorname{liter}^{-1} \mathrm{pH} 6.5 ; 15 \% \mathrm{~N}-1 \mathrm{NH}_{4}^{+}: 10\right.$ $\mathrm{NO}_{3}: 2$ urea: $15 \% \mathrm{P}_{2} \mathrm{O}_{5}$ and $18 \% \mathrm{~K}_{2} \mathrm{O}$ ) (Table 1) was applied twice

Received for publication 28 June 1994. Accepted for publication 4 Oct. 1994. The cost of publishing this paper was defrayed in part by the payment of page charges. under postal rcgulations, this paper therefore must be hereby marked advertisement solely to indicate this fact.

${ }^{1}$ Present address: Dept. of Horticulture and Forestry, Univ. of Arkansas, Fayetteville, AR 72701.

${ }^{2}$ Associatc professor. a week to the seedlings after leaf emergence and until the plants grew to $10-12 \mathrm{~cm}$ (2-3 weeks).

Correlation among evaluation parameters. Ten uniform seedlings from each of green leaf (GA 102. GF305, Nemaguard, P1442378, Gaschina Novembre, Montclar, NJ672281007) and red leaf (152 AIRH2, Higama, Nemared, R26-2, Rubira, Starks Red Leaf, 'Titun' $x$ Nemared, TXR5989-1R, TXR5989-5R and TXR5989-6) rootstocks were selected. The medium was leached with three pot volumes of $\mathrm{K}_{2} \mathrm{CO}_{3}$-amended nutrient solution. Pots were set in the large pans on fiberglass saturated with $\mathrm{K}_{2} \mathrm{C} \mathrm{O}_{3}$ amended nutrient solution.

Leaf visual chlorosis was rated as follows: $1=$ healthy green or healthy red leaves; 2 = green and red leaves with slightly yellow interveinal areas. 3 = leaves with distinct yellowing over most of the leaves but the veins remained green. or red leaves with most parts of leaves light red: $4=$ whole leaf yellow except green midvein, or pale red interveinal areas with pale-green veins; $5=$ whole leaf yellow, or very pale-red interveinal areas with greenish-white veins (Byrne, 1988). When Nemaguard was very chlorotic (leaf visua-chlorosis rating $=5$, Spad-502 chlorophyll reading $(\leq 10)$. 10 newly mature leaves from each seedling were collected and rated for leaf visual-chlorosis, and their chlorophyll content was measured with a Spad-502 chlorophyll meter. Leaf visua-chlorosis rating. Spad-502 chlorophyll reading were averaged over 10 leaves, and the 10-leaf composite sample was used to measure the DMSO (dimethyl sulfoxide) extractable leaf chlorophyll concentration (Hiscox and Israelstam, 1979: Bruinsma, 1963). A correlation analysis was performed by 'Proc Corr' procedure (SAS Institute, 1985).

Rootstock evaluation. A minimum of five uniform seedlings of each of 48 Prunus accessions were evaluated with a Nemaguard control in eight separate trials in the greenhouse on top of fiberglass saturated with the $\mathrm{K}_{2} \mathrm{C} \mathrm{O}_{3}$-screening solution as described previously. The seedlings were grown individually in pots. Once they were 10 to $12 \mathrm{~cm}$ tall, uniform seedlings were selected. and cut back to $8 \mathrm{~cm}$ (Wallace, 1988). Leaf visual-chlorosis ratings and Spad-502 chlorophyll readings were taken when the seedlings had grown an additional $8 \mathrm{~cm}$ or when Nemaguard controls were very chlorotic (lest'visual-chlorosis rating ( $\geq 4$ or Spad-502 chlorophyll reading $(\leq 10)$ which was usually after 1 month. All rootstock were evaluated within a 4-month period (Jan. to Apr., 1990). A completely randomized design was used within a given trial and all the rootstock were compared to the control rootstock, Nemaguard. The number of tests depended on the number of seedlings available from each rootstock. 
Table 1. Nutrient concentrations of normal $\left(\mathrm{pH}\right.$ 6.5) and $\mathrm{K}_{2} \mathrm{CO}_{3}$-amended Plantcx nutrient solution ( $\mathrm{pH}$ 8.5).

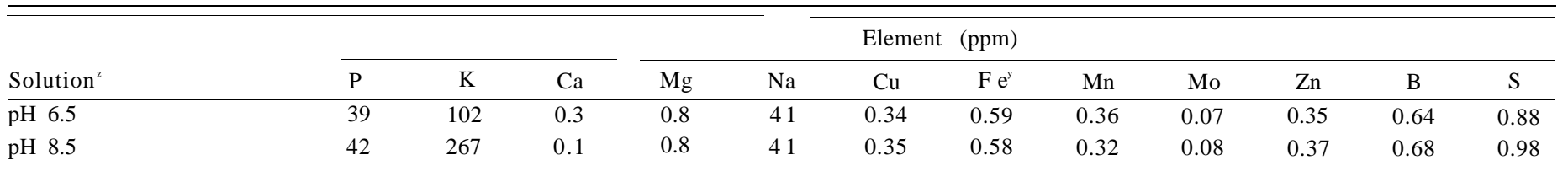

${ }^{\overline{2}}$ This solution was prepared by adding Plantex $\left(0.57\right.$ g.liter $\left.{ }^{-1}\right)$ to reverse osmosis-purified water and the $\mathrm{pH}$ was raised to 8.5 by adding $\mathrm{K}_{2} \mathrm{CO}_{3}\left(0.25 \mathrm{~g} \cdot 1\right.$ liter $\left.{ }^{-1}\right)$, ${ }^{y}$ Iron chelate used is FeEDTA.

Nutrient and bicarbonate (Nelson, 1982) levels of newly made Plantex (0.57 g.liter ${ }^{-1}$ Plantex, $\mathrm{pH}$ 6.5) and $\mathrm{KaCO}_{3}$-amended nutrient solutions were analyzed. Potassium, $\mathrm{Ca}, \mathrm{Mg}, \mathrm{Mn}, \mathrm{Fe}$, and $\mathrm{Zn}$ were measured with a 3510 ICP spectrophotometer (Advanced Research Lab, Sunyland, Calif. ) and $\mathrm{N}$ and $\mathrm{P}$ were analyzed with a Technicon Autoanalyzer. The experiments were conducted in a greenhouse at Texas A\&M Univ. (College Station) with a PAR (photosynthetically active radiation) range of 400 to 1000 $\mathrm{mol} \cdot \mathrm{m}^{-2} \mathrm{~s}^{-1}$ a relative humidity of $80 \pm 11 \%$ (max. $91 \%$ and $\min .69 \%$ ) and day and night temperatures of $26 \pm 6 \mathrm{C}$ (max. 32C and min. 20C) and $22 \pm 2 \mathrm{C}$ (max. 24C and min. 20C), respectively. Due to the consistency of results among experiments and their similarity in variances, the data were combined over experiments. An analysis of variance with $\operatorname{LSD}(P=0.05)$ was used.

\section{Results and Discussion}

Correlation among evaluation parameters. Leaf visual-chlorosis ratings were highly correlated with the Spad-502 chlorophyll reading for both green-and red-leaf peach rootstocks $(r=-0.97 *)$. Green-leaf rootstock had higher $\mathrm{cm}$-relations between leaf visuachlorosis rating with extractable leaf-chlorophyll concentration than the red-leaf rootstock $(r=0.90 *$ vs. $0.80 *)$. The lower correlations for red leaf rootstock were due to some unexpectedly low chlorophyll levels for Titan x Nemared and TXR5989-1R, When these points were removed, the correlation between leaf visual-chlorosis rating or Spad-502 chlorophyll reading with extractable leaf-chlorophyll concentration was $0.91 *$. Since the chlorophyll levels were well correlated with leaf-visual chlorosis ratings and Spad-502 chlorophyll readings, either of these may be used to evaluate the degree of chlorosis as reported for other crops (DeCianzio et al.. 1979: Marquard and Tipton, 1987: Mckenzie et al., 1984; Rashid et al., 1990).

Relative tolerance to bicarbonate-induced chlorosis of peach rootstock. Leaf visual-chlorosis ratings and Spad-502 chlorophyll readings varied with the rootstock evaluated (Table 2). Leaf visual-chlorosis ratings were inversely related to Spad-502 chlorophyll reading. Nemaguard, the control rootstock, was susceptible to bicarbonate-induced chlorosis (low Spad-502 chlorophyll reading and high leaf visual -chlorosis rating), and most rootstocks were more tolerant than Nemaguard. In future comparisons among the more tolerant rootstock, a moderately tolerant control would be useful.

'Titan' x Nemared and 'Titan' x Nemaguard have been reported to be tolerant to $\mathrm{Fe}$ chlorosis in calcarcosis soils (Byrne, 1988) and in high bicarbonate or low Fe solution culture (Byrne et al., 1990: Romera et al., 1991), which agrees with the current evaluation, Many of the most tolerant accessions in this test are peach-almond hybrid lines (TXR4989-2, 'Titan' x Nemaguard. TXR5989-7R. 'Titan' x Nernared, TXR5989-1R) which obtain their tolerance from their almond parentage (Byrne et al,, 1989; Egilla and Byrne, 1989; Kester and Hansen, 1966): however. some rootstocks with almond parentage. such as USSR0137 and TXR4989-1R, did not appear to be tolerant in the current study. Although most peach
Table 2, Means of chlorosis ratings and Spad readings of peach rootstocks evaluated in 1 vermiculite : 1 perlite medium (v/v) using $\mathrm{K}_{2} \mathrm{CO}_{3}^{-}$ amended nutrient solution in the greenhouse.

\begin{tabular}{|c|c|c|c|c|}
\hline \multirow[b]{2}{*}{ Rootstock } & \multicolumn{2}{|c|}{ Mean } & \multirow[b]{2}{*}{$\begin{array}{l}\text { No. } \\
\text { rests }\end{array}$} & \multirow[b]{2}{*}{$\begin{array}{c}\text { No. } \\
\text { plants }\end{array}$} \\
\hline & $\begin{array}{l}\text { Chlorosis } \\
\text { rating }\end{array}$ & $\begin{array}{l}\text { Spad } \\
\text { reading }\end{array}$ & & \\
\hline TXR4989-2 & 1.7 & 34 & 2 & 16 \\
\hline Swat & 1.8 & 32 & 1 & 9 \\
\hline Titan $x$ Nemared & 1.9 & 31 & 3 & 28 \\
\hline TXR5989-7R & 1.9 & 30 & 2 & 15 \\
\hline Tiran $\times$ Nemaguard & 2.1 & 28 & 2 & 16 \\
\hline TXR5989-IR & 2.1 & 28 & 4 & 18 \\
\hline NJ6722810007 & 2.3 & 27 & 2 & 29 \\
\hline Prisco Veracruz & 2.3 & 27 & 1 & 9 \\
\hline Liveoak & 2.1 & 27 & 1 & 12 \\
\hline Clarkhill plum & 2.3 & 26 & 2 & 36 \\
\hline Montclat & 2.5 & 26 & 3 & 15 \\
\hline TXR5989-5R & 2.3 & 25 & 1 & 18 \\
\hline TXR4989-1R & 2.4 & 25 & 2 & 18 \\
\hline Bolivian Cling & 2.5 & 25 & 1 & 8 \\
\hline PI442378 & 2.5 & 25 & 3 & 26 \\
\hline Rubira & 2.4 & 25 & 1 & 30 \\
\hline Starks Red Leaf & 2.3 & 24 & 2 & 20 \\
\hline Mexico sdlg & 2.5 & 23 & 3 & 17 \\
\hline Rutgers Red Leal & 2.4 & 23 & 2 & 17 \\
\hline USSRO1.37 & 2.5 & 23 & 2 & 22 \\
\hline Rancho Resistant & 2.6 & 23 & 2 & 16 \\
\hline Siberian C & 2.7 & 23 & 1 & 9 \\
\hline PI55776 & 2.7 & 23 & 1 & 10 \\
\hline Indian Cling & 2.7 & 22 & 1 & 12 \\
\hline$B Y 520-9$ & 2.8 & 22 & 1 & 8 \\
\hline Agua6-4 & 2.9 & 22 & 1 & 12 \\
\hline Nematred & 2.8 & 22 & 2 & 18 \\
\hline Trancvaal Yollow & 2.8 & 22 & 2 & 22 \\
\hline$J 68-271$ & 2.8 & 21 & 1 & 10 \\
\hline TXR4989-4 & 2.8 & $2 !$ & 3 & 21 \\
\hline TXR1588-1 & 2.6 & 21 & 2 & 23 \\
\hline IXR5989-6 & 2.9 & 21 & 3 & 26 \\
\hline Baladi & 2.9 & 20 & 3 & 35 \\
\hline Boone County & 2.9 & 20) & 1 & 20 \\
\hline$N .162,325$ & 3.0 & 20 & 2 & 22 \\
\hline Kathamas & 3.1 & 20 & 1 & 10 \\
\hline SCRS-1 & 3.1 & 20 & 3 & 18 \\
\hline Prumus ferganesis & 2.8 & 20 & 1 & 12 \\
\hline Higanala & 3.0 & 20 & 1 & 11 \\
\hline Prumus davidiana & 3.1 & 20 & 3 & 23 \\
\hline$T 01-13$ & 3.0 & 19 & 3 & 24 \\
\hline$S 82$ & 3.0 & 19 & 2 & 24 \\
\hline $\mathrm{BY} \times 2 \mathrm{P} 6212$ & 3.1 & 18 & 2 & 16 \\
\hline TXR4989-3 & 3.3 & 18 & 2 & 26 \\
\hline Bangalow & 3.4 & 16 & 2 & 16 \\
\hline Salcaja & 3.5 & 14 & 1 & 12 \\
\hline Nemaguard & 3.7 & 14 & 8 & 475 \\
\hline$S 16.3$ & 44 & 9 & 1 & 5 \\
\hline $1.5 \mathrm{D}(5 \%)$ & 0.5 & 4.1 & & \\
\hline
\end{tabular}


seedlings are susceptible to bicarbonate-induced Fe chlorosis, Montclar and a few other selections have been reported to be moderately susceptible to moderately tolerant (Egilla and Byrne, 1989). Generally, the same results were obtained in this study. However, several peach genotypes (NJ672281007 and 'Swat') showed a moderate to high level of tolerance. It was encouraging that a moderate level of tolerance does exist among peaches. Using peach as a source of tolerance would avoid the disadvantages of using almond, which has poor propagation qualities and is more susceptible than peach to water logging, nematodes and crown gall (Egilla and Byrne, 1989; Layne, 1987; Rom, 1983).

\section{Literature Cited}

Bruinsma, J. 1963. The quantitative analysis of chlorophylls a and b in plant extracts. Photochem. Photobiol. 2:241-249.

Byrne, D.H. 1988. Comparative growth of the peach seedling rootstocks under alkaline soil condition. J. Plant Nutr. 11:1663-1669.

Byrne, D.H., T.A. Bacon and J.N.A. Egilla. 1990. Stone fruit rootstocks tolerant to calcareous soils (Patrones de frutales de hueso tolerantes a suelos calizos). XXII Jomadas de AIDA ITEA (Spain) 9:119-133.

Byrne, D.H., T. Bacon and J.N. Egilla. 1989. Developing peach root stocks for calcareous soils. Compact Fruit Tree 22:87-90.

Chaney, R.L., P.F. Bell, and B.A. Coulombe. 1989. Screening strategies for improved nutrient uptake and use by plants. HortSci. 24:565-572.

Coulombe, B.A., R.L. Chaney and W.J. Weibold. 1984. Use of bicarbonate in screening soybeans for resistance to iron chlorosis. J. Plant Nutr. 7:411-425.

DeCianzio, S.R., W.R. Fehr and I.C. Anderson. 1979. Genotypic evaluation for iron deficiency chlorosis in soybeans by visual scores and chlorophyll concentration. Crop Sci. 19:644-646.

Dragonuk, M.B., W.R. Fehr and H.J. Jessen. 1989. Nutrient-solution techniques for evaluation of iron efficiency of soybean. J. Plant Nutr.
12:871-880.

Egilla, J.N. and D.H. Byrne. 1989. The search for peach rootstocks tolerant to alkalinity. Fruit Var. J. 43:7-11.

Hiscox, J.D. and G.F. Israelstam. 1979. A method for the extraction of chlorophyll from leaf tissue without maceration. Can. J. Bot. 57: 13321334 .

Kester, D.E. and C.J. Hansen. 1966. Rootstock potentialities of F, hybrids between peach (Prunus persica L.) and almond (Prunus amygdalus Batsch.). Amer. Soc. Hort. Sci. 89:101-109.

Layne, R.E.C. 1987. Peach rootstocks, p. 185-216. In: R. C. Rom and R. F. Carlson (ed.). Rootstocks for fruit crops. John Wiley \& Sons, New York. Marquard, R.D. and J.L. Tipton. 1987. Relationship between extractable chlorophyll and an in situ method to estimate leaf greenness. HortScience. 22:1327.

Mckenzie, D.B., L.R. Hossner and R.J. Newton. 1984. Sorghum cultivar evaluation for iron chlorosis resistance by visual scores. J. Plant Nutr. 7:677-685

Nelson, R.E. 1982. Carbonate and gypsum, p. 181-197. In: A.L. Page (ed.). Methods of soil analysis. 2nd. ed. Madison, Wis.

Rashid, A., G.A. Couvillon and J.B. Jones. 1990. Assessment of Fe status of peach rootstocks by techniques used to distinguish chlorotic and nonchlorotic leaves. J. Plant Nutr. 13:285-307.

Rom, R.C. 1983. The peach rootstock situation: An international perspective. Fruit Var. J. 37:3-14.

Romera, F.J., E. Alcantara and M.D Guardia. 1991. Characterization of the tolerance to iron chlorosis in different peach rootstocks grown in nutrient solution. 1. Effect of bicarbonate and phosphate. Plant and Soil 130:115-119.

SAS Institute. 1985. SAS User's guide: Statistics. 5th ed. SAS Institute, Gary, N.C.

Wallace, A. 1988. Iron chlorosis induced by detopping soybeans. J. Plant Nutr. 11:793-796.

Wallace, A. and O.R. Lunt. 1960. Iron chlorosis in horticultural plants, A review. Amer. Soc. Hort. Sci. 7:819-841. 